\title{
Hyperthermic Modulation of the Seedling and Genetic Damage Produced by a Chemical Mutagen in Plants
}

\author{
B. L. Kaul \\ Regional Research Laboratory, Jammu (Tawi) 180001, India
}

Accepted June 11, 1985

Hyperthermia alone and in combination with ionizing radiations has in recent years been shown to be useful in selective killing of tumour cells. A considerable amount of work is presently being carried out to find out its efficacy as an adjuvant to current therapeutic techniques in cancer therapy. Hyperthermic treatment of mammalian cells within the range of $42-48^{\circ} \mathrm{C}$ causes cell killing (Westra and Dewey 1971, Plazer and Heidelberger 1973); blockage of cell progression through cell cycle (Gerweck and Dewey 1975); chromosomal aberrations (Dewey et al. 1971) and an increased sensitivity to X-irradiation (Ben-Hur et al. 1974, Henle and Leeper 1976). There is, however, no information whether response of cells to chemical mutagens is also modified in the same way nor has it been verified whether these observations can hold true in the case of higher plant systems also. The present investigations were conducted to provide information and possible insight into the mode of action of hyperthermia alone and in combination with a chemical mutagen in barley seeds.

\section{Materials and methods}

Dormant caryopsis of barley (Hordeum vulgare L.) var. Himilaya formed the test system. Solution of mutagen 1, 3 propane sultone (PS), Sigma, USA, was freshly prepared in distilled water and 4 and $8 \mathrm{mM}$ solutions were generally used in the experiments. For hyperthermic treatments, seeds were placed in preheated ovens at $35^{\circ} \mathrm{C}$ or $45^{\circ} \mathrm{C}$ for specific periods of time either immediately before, concomitant or immediately following PS treatments. Details have been given in each experiment.

Treatments were carried out in three replications. In each case 50 seeds were soaked in $25 \mathrm{ml}$ of the test solution and treatments terminated by giving them a quick rinse in running water, planted on moist filter papers in sterile plastic petri dishes and allowed to germinate. Seedling height was measured when primary leaf had stopped further growth. Root tips about $1 \mathrm{~cm}$ long were fixed in acetic acid: alcohol (1:3) and squash preparations prepared according to Feulgen technique. At least 100 cells in each treatment were scored to assess cytological damage.

\section{Results}

Data presented in Table 1 show that a hyperthermic pretreatment $\left(45^{\circ} \mathrm{C}\right)$ reduces the seedling injury from $36 \%$ to a mere $8 \%$. Similarly $20.9 \%$ root injury 

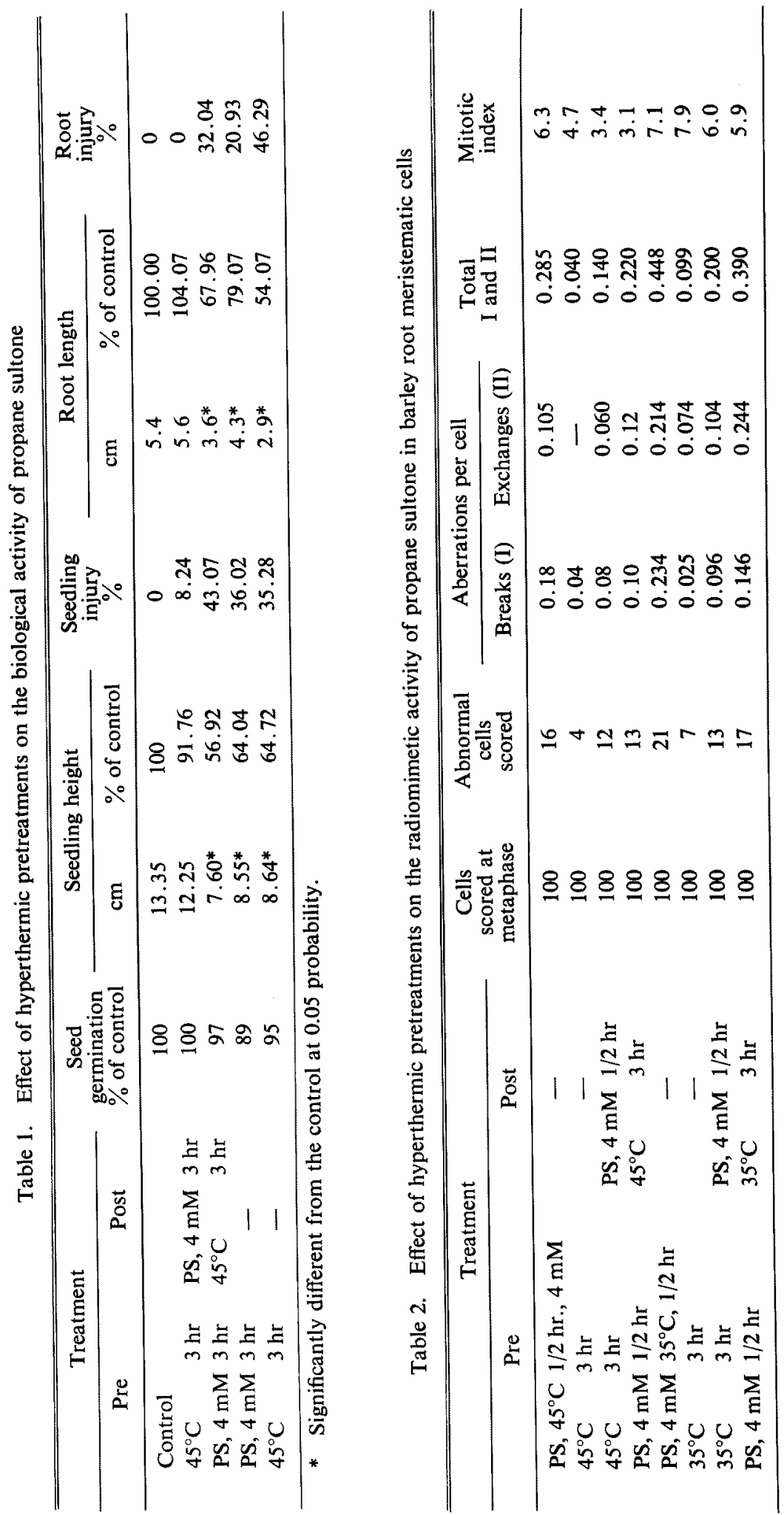
produced by PS was totally eliminated by hyperthermic pretreatment. However, hyperthermic post treatment did not have similar effects either with respect to seedling injury or root injury.

To study the effect of hyperthermic pretreatment on the chromosome breaking activity of PS, two hyperthermic treatments $\left(35^{\circ} \mathrm{C}\right.$ and $\left.45^{\circ} \mathrm{C}\right)$ for 3 hours were administered. It can be seen from Table 2 that total aberrations per cell were reduced by almost one half and there was also a significant reduction in number of abnormal cells. Thus, it is clearly brought out by the data in Tables 1 and 2 that hyperthermic pretreatments provide a strong protection against the mutagenic damage produced by PS in terms of seed or seedling injury, root injury as well as chromosomal aberrations.

Table 3. Effect of hyperthermic treatments on the biological activity of propane sultone $\left(8 \mathrm{mM}, 2 \mathrm{hr}, 30^{\circ} \mathrm{C}\right)$

\begin{tabular}{|c|c|c|c|c|c|c|c|}
\hline \multicolumn{2}{|c|}{ Treatment } & \multirow{2}{*}{$\begin{array}{l}\text { Seedling } \\
\text { height, } \\
\mathrm{cm}\end{array}$} & \multirow{2}{*}{$\begin{array}{c}\text { Increase } \\
\text { over } \\
\text { control } \\
\%\end{array}$} & \multirow{2}{*}{$\begin{array}{c}\text { Root } \\
\text { length } \\
\mathrm{cm}\end{array}$} & \multirow{2}{*}{$\begin{array}{c}\text { Increase } \\
\text { over } \\
\text { control } \\
\%\end{array}$} & \multirow{2}{*}{$\begin{array}{l}\text { Seed } \\
\text { germi- } \\
\text { nation } \\
\%\end{array}$} & \multirow{2}{*}{$\begin{array}{c}\text { Increase } \\
\text { over } \\
\text { control } \\
\%\end{array}$} \\
\hline Pre & Post & & & & & & \\
\hline PS & - & 3.65 & - & 0.81 & - & 48 & - \\
\hline $45^{\circ} \mathrm{C} 1 \mathrm{hr}$ & PS & $5.76^{*}$ & 57.26 & 2.06 & 155.1 & $72.5^{*}$ & 51.4 \\
\hline $45^{\circ} \mathrm{C} 2 \mathrm{hr}$ & PS & $5.71^{*}$ & 56.44 & 1.95 & 140.7 & $78.4^{*}$ & 63.7 \\
\hline $45^{\circ} \mathrm{C} 3 \mathrm{hr}$ & PS & $6.04 *$ & 65.48 & 2.03 & 150.6 & $71.2^{*}$ & 48.6 \\
\hline $45^{\circ} \mathrm{C} 4 \mathrm{hr}$ & PS & $4.80^{*}$ & 31.51 & 1.68 & 107.4 & 61.3 & 27.9 \\
\hline
\end{tabular}

* Significantly different from the control at 0.05 probability.

Table 4. Comparative effect of various durations of hyperthermic pretreatments on the radiomimetic activity of propane sultone $\left(8 \mathrm{mM}, 3 \mathrm{hr}, 30^{\circ} \mathrm{C}\right)$

\begin{tabular}{|c|c|c|c|c|c|c|c|c|}
\hline \multicolumn{2}{|c|}{ Treatment } & \multirow{2}{*}{$\begin{array}{l}\text { Cells } \\
\text { scored at } \\
\text { meta- } \\
\text { phase }\end{array}$} & \multirow{2}{*}{$\underset{\%}{\text { Abnormal }}$} & \multicolumn{2}{|c|}{ Aberrations $\%$} & \multirow{2}{*}{$\begin{array}{c}\text { Total } \\
\text { aberra- } \\
\text { tions } \\
\text { I and II } \\
\%\end{array}$} & \multirow{2}{*}{$\begin{array}{c}\text { Reduc- } \\
\text { tion } \\
\text { over } \\
\text { control } \\
\%\end{array}$} & \multirow{2}{*}{$\begin{array}{l}\text { Mitoic } \\
\text { index }\end{array}$} \\
\hline Pre & Post & & & $\begin{array}{l}\text { Breaks } \\
\text { (I) }\end{array}$ & $\begin{array}{l}\text { Exchanges } \\
\text { (II) }\end{array}$ & & & \\
\hline PS & - & 100 & 32 & 0.975 & 0.025 & 1.010 & - & 7.4 \\
\hline $45^{\circ} \mathrm{C} 1 \mathrm{hr}$ & PS & 100 & 38 & 0.596 & 0.016 & 0.612 & 39.40 & 5.6 \\
\hline $45^{\circ} \mathrm{C} 2 \mathrm{hr}$ & PS & 100 & 26 & 0.274 & 0.016 & 0.290 & 71.29 & 4.9 \\
\hline $45^{\circ} \mathrm{C} 3 \mathrm{hr}$ & PS & 100 & 11 & 0.237 & 0 & 0.237 & 76.53 & 4.1 \\
\hline $45^{\circ} \mathrm{C} 4 \mathrm{hr}$ & PS & 100 & 23 & 0.435 & 0 & 0.435 & 56.93 & 3.9 \\
\hline
\end{tabular}

To estimate the period of exposure to hyperthermia necessary to give protection, seeds were pretreated for 1 to 4 hours at $45^{\circ} \mathrm{C}$ before exposing them to PS treatment. Data are presented in Tables 3 and 4. Protection was evident following all the hyperthermic pretreatments, a 3 hour pretreatment showing the maximum protection. Prolonged posttreatments $(5 \mathrm{hr})$ also seem to offer protection (Table 5).

Weather hypothermic treatments could also have similar effects an experiment was conducted treating seeds to $5^{\circ} \mathrm{C}$ for three hours period prior to or following PS treatments. Low temperature treatment by itself had no effect nor did it increase or decrease the activity of PS (Table 6). 

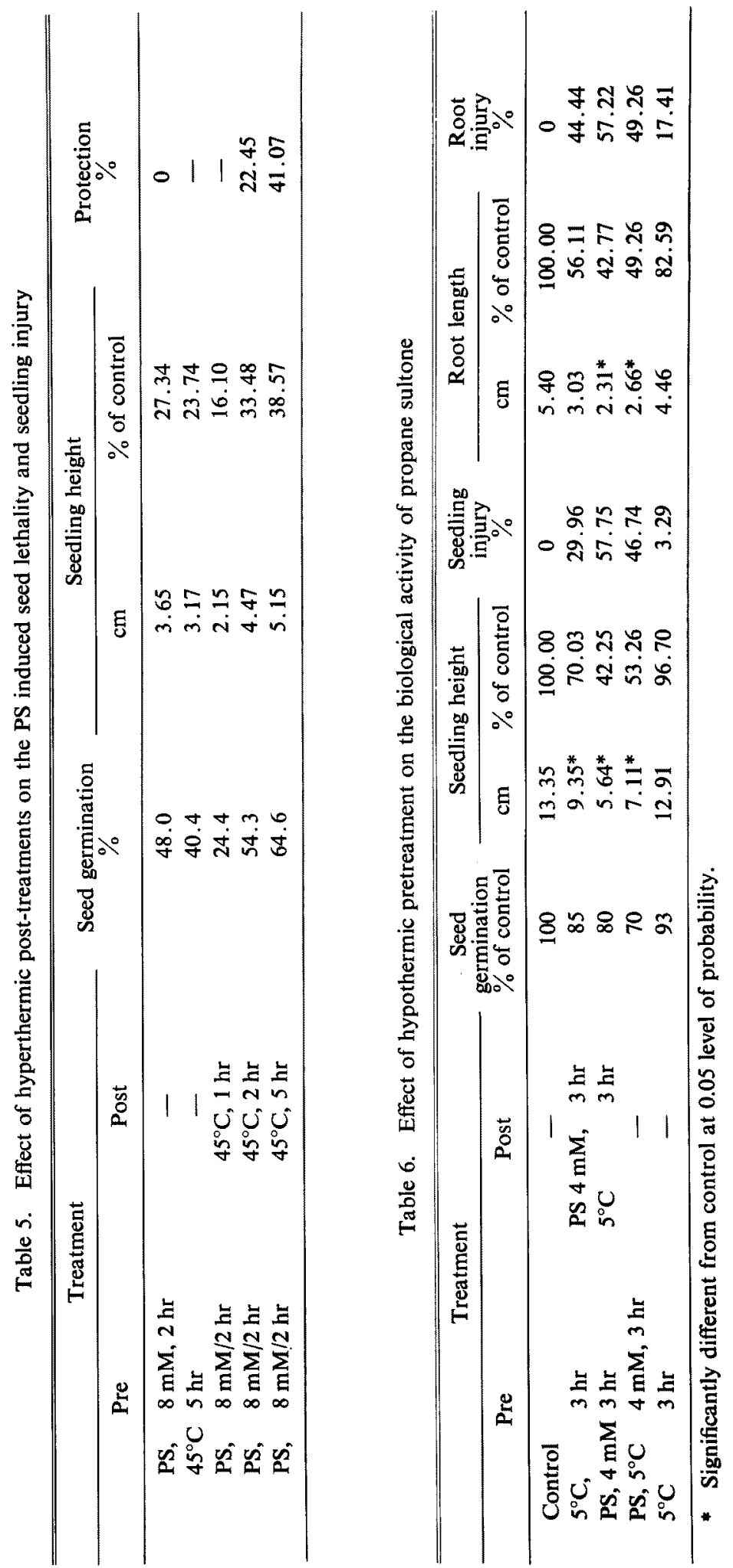


\section{Discussion}

The data gathered through these experiments show that hyperthermic pretreatments reduce the biological damage produced by PS, which is reflected in various parameters like seed lethality, seedling injury, root injury as well as chromosomal aberrations. Both hyperthermia as well as PS when applied alone produced considerable genetic damage. However, to understand this paradoxical situation we may have to explain the mechanism of PS action first. The activity of PS is a result of a specific chemical reaction between the mutagen and DNA (Osterman-Golkar and Wachtmeister 1976). It has been clearly shown that PS reacts with cellular macromolecules producing complexes made of nucleic acid and proteins (Zeldin et al. 1975) and S-phase of cell division is the most sensitive stage for these reactions (Kaul 1969). For these reactions to take place it is also necessary that cells are in an active metabolic state.

It has been reported by many workers that the progression of cell cycles and duration of its various phases are highly sensitive to temperature stress. Both at low temperature $\left(3^{\circ}-4^{\circ} \mathrm{C}\right)$ or high temperature $\left(30^{\circ} \mathrm{C}\right)$ the duration and the mitotic cycle time decreases (see Rost 1977). Obviously, at such high temperature (e.g. $45^{\circ} \mathrm{C}$ ) the cell proliferation is reduced to almost zero (Burholt and Van't Hof 1971). The key to explaining the protective effect of temperature may lie in this fact, as at higher temperature the mitotic index falls very rapidly and target molecules for mutagenic reaction are not available. Hence, no real genetic damage takes place.

In an analogous situation it was shown by Caldecot and Smith (1952) that dry barley seeds exposed to heat shock of about $80^{\circ} \mathrm{C}$ for half an hour either before or immediately after $\mathrm{X}$-irradiation reduced induced chromosome breakage frequency by about one half. This observation was later on confirmed by many independent studies using dry seed system (Caldecot 1961, Konzak et al. 1961) though no satisfactory explanation for thermal restoration was provided. It was also shown that storage effect in dry seed irradiation was strongly temperature dependent (see Caldecot 1961).

\section{Summary}

Experiments were conducted to find out the influence of hyperthermic treatments on the biological activity of 1,3-propane sultone. Hyperthermic $\left(35-45^{\circ} \mathrm{C}\right)$ pretreatments for 1-4 hours gave significant protection against the biological damage produced by the mutagen. Seedling injury was reduced from 36 to $8 \%$ and root injury totally eliminated. Chromosome aberrations in root tip cells were reduced by one half. Hyperthermic post-treatments, however, were ineffective.

\section{References}

Ben-Hur, E., Elkind, M. M. and Bronk, B. V. 1974. Thermally enhanced radioresponse of cultured clunese hamster cells: Inhibition of repair of sub-lethal damage and enhancement of lethal damage. Radiat. Res. 58: 38-51.

Burholt, D. R. and Van't Hof, J. 1971. Quantitative thermal induced changes in growth and cell population kinetics of Helianthus root. Am. J. Bot. 58: 386-393. 
Caldecot, R. S. 1961. Seedling height, oxygen availability, storage and temperature: Their relation to radiation induced genetic and seedling injury in barley. The effects of ionizing radiation on seeds. IAEA, Vienna: 3-24.

- and Smith, L. 1952. Influence of heat treatments on the injury and cytogenetic effects of X-rays on barley. Genetics 37: 136-157.

Dewey, W. C., Westra, A., Miller, H. H. and Nagasawa, H. 1971. Heat induced lethality and chromosome damage in synchronized chinese hamster cells treated with 5-bromodeoxyuridine. Int. J. Radiat. Biol. 20: 505-520.

Gerweck, L. E. and Dewey, W. C. 1975 . Variation in response to heat during the mammalian cell cycle. In Proceedings of the International Symposium on Cancer Therapy by Hyperthermia and Radiation, Washington, D. C. pp. 16-26.

Henle, K. J. and Leeper, D. B. 1976. Interaction of hyperthermia and radiation in CHO cells: Recovery kinetics. Radiat. Res. 66 : 505-518.

Kaul, B. L. 1969. Production of chromosome aberrations by propane sultone in Vicia faba. Mutation Res. 7: 339-347.

Konzak, C. F., Nilan, R. A., Legault, R. R. and Heiner, R. E. 1961. Modification of induced genetic damage in seeds: Effects of ionizing radiation on seeds. IAEA, Vienna: 155-169.

Osterman-Golker, S. and Wachtmeister, C. A. 1976. On the reaction kinetics in water of 1,3propane sultone and 1,4-butane sultone: A comparison of reaction rates and mutagenic activity of some alkylating agents. Chem. Biol. Interact. 14: 195-202.

Palzer, R. J. and Heidelberger, C. 1973. Studies on the quantitative biology of hyperthermic killing of HeLa cells. Cancer Res. 33: 415-421.

Rost, T. L. 1977. Responses of plant cell cycle to stress. In Mechanism and Control of Cell Division (Stroudsbug PA: Dowson, Hutchinson and Ross, Inc.), pp. 111-143.

Westra, A. and Dewey, W. C. 1971. Variation in sensitivity to heat shock during the cell cycle of chinese hamster cells in vitro. Int. J. Radiat. Biol. 19: 467-477.

Zeldin, P. E., Battacharya, P. K., Kubinski, H. and Nictert, W. C. 1975. Macromolecular complexes produced by 1.3, propane sultone. Cancer Res. 35: 1445-1452. 